\title{
COMPELLED SUBSIDIZATION OF \\ SPEECH: JOHANNS $v$ LIVESTOCK \\ MARKETING ASSOCIATION
}

In recent years the Supreme Court has decided a spate of cases about the compelled subsidization of speech. ${ }^{1}$ All have involved federal statutes creating industry boards empowered to tax producers of specific agricultural products in order to promote and stabilize the market in those products. Some of these statutes were enacted during the New Deal era, ${ }^{2}$ whereas others are quite recent. ${ }^{3}$ In the past decade these statutes have been challenged on the ground that they compel producers to subsidize objectionable commercial advertisements. The resulting cases have raised conceptually difficult and complex First Amendment questions, which the Court has proved unable to master.

At first, in Glickman v Wileman Bros. \& Elliott, ${ }^{4}$ the Court upheld a federal marketing program for California summer fruits that required private parties to subsidize an advertising campaign. Dis-

Robert Post is David Boies Professor of Law, Yale Law School.

AurHoR's NoTE: I am grateful for the immensely helpful comments of Don Herzog, Fred Schauer, Reva Siegel, Geof Stone, and Jim Weinstein, as well as for the invaluable assistance of David Newman, Matt Spence, Robert Wiygul, and Mark Wu.

${ }^{1}$ Glickman v Wileman Bros. \& Elliott, 521 US 457 (1997); United States v United Foods, Inc., 533 US 405 (2001); fobanns v Livestock Mktg Ass'n, 125 S Ct 2055 (2005).

2 Glickman, 521 US at 461.

${ }^{3}$ United Foods, 533 US at 408.

4521 US 457 (1997).

(C) 2006 by The University of Chicago. All rights reserved.

$0-226-36251-5 / 2006 / 2005-0005 \$ 10.00$ 
missing claims that this mandated subsidization amounted to compelled speech in violation of the First Amendment, the Court in a narrow five-to-four opinion held that "our compelled speech case law . . . is clearly inapplicable to the regulatory scheme at issue here." Four years later the Court reversed course, and in United States $v$ United Foods, Inc. ${ }^{6}$ struck down a program designed to promote and stabilize the market in fresh mushrooms. The opinion, joined by six Justices, announced that "First Amendment concerns apply" whenever the state requires persons to "subsidize speech with which they disagree."

The Court's opinion in United Foods sparked a cascade of lowercourt decisions that rapidly developed what may be called compelled subsidization of speech doctrine, ${ }^{8}$ which in the remainder of this article I shall refer to as "CSSD." United Foods set forth the basic premise of CSSD: First Amendment scrutiny is triggered whenever someone is forced to pay for speech that she finds objectionable. Because taxation involves the compelled subsidization of government speech, an obvious difficulty with this premise is that it seems to imply that constitutional scrutiny is required every time a taxpayer disagrees with government messages supported by her tax dollars. This is plainly an untenable position, yet the seemingly inexorable pressure of CSSD led the Eighth Circuit in Livestock Marketing Ass' $n v$ Department of Agriculture ${ }^{9}$ to conclude that "a determination that the expression at issue is government speech

${ }^{5}$ Id at 470 .

6533 US 405 (2001)

${ }^{7}$ Id at 410-11. An important question, which I shall not discuss in this article, is whether and how compelled speech doctrine ought to apply to the kind of commercial speech that is at issue in these cases. See note 117 below.

${ }^{8}$ See, e.g., Pelts or Skins, LLC v Landreneau, 365 F3d 423 (5th Cir 2004) (Louisiana Alligator Resource Fund), vacated, 125 S Ct 2511 (2005); Cocbran v Veneman, 359 F3d 263 (3d Cir 2004) (Dairy Promotion Stabilization Act of 1983), vacated sub nom, Lovell $v$ Cocbran, 125 S Ct 2511 (2005), and 7ohanns v Cocbran, 125 S Ct 2512 (2005); Mich. Pork Producers Ass'n v Veneman, 348 F3d 157 (6th Cir 2003) (Pork Promotion, Research and Consumer Information Act), vacated sub nom, Mich. Pork Producer Ass'nv Campaign for Family Farms, 125 S Ct 2511 (2005), and Johanns v Campaign for Family Farms, 125 S Ct 2511 (2005); Delano Farms Co. v Cal. Table Grape Comm'n, 318 F3d 895 (9th Cir 2003) (California Table Grape Commission); In re Wash. State Apple Adver. Comm'n, 257 F Supp 2d 1290 (ED Wash 2003) (Washington State Apple Commission); Charter v U.S. Dep't of Agr., 230 F Supp 2d 1121 (D Mont 2002), vacated, 412 F3d 1017 (9th Cir 2005); Gerawvan Farming, Inc. v Kawamura, 90 P3d 1179 (Cal 2004); Dep't of Citrus v Graves Bros. Co., 889 So2d 831 (Fla Dist Ct App 2004).

9335 F3d 711 (8th Cir 2003), vacated sub nom, fohanns v Livestock Mktg. Ass'n, $125 \mathrm{~S}$ Ct 2055 (2005). 
does not preclude First Amendment scrutiny in the compelled speech context." 10

The Supreme Court acted swiftly to check this radical implication of its own doctrine. Last Term in Fobanns $v$ Livestock Marketing $A s s^{\prime} n^{11}$ it reversed the Eighth Circuit to hold "that compelled funding of government speech does not alone raise First Amendment concerns."12 Although Johanns is quite definite that citizens "have no First Amendment right not to fund government speech," ${ }^{13}$ it never offers a theoretical account of why taxation is an exception to the basic premise of CSSD. Fobanns instead stresses the practical point that "it seems inevitable that funds raised by the government will be spent for speech and other expression to advocate and defend its own policies."14 The exemption accorded by fobanns to government speech is thus a blunt ipse dixit; it does not prompt the Court to reconsider the basic framework of CSSD.

This is unfortunate, for CSSD's failure to explain why taxation should not prompt constitutional scrutiny is merely the surface manifestation of deep conceptual insufficiencies. Indeed, I shall argue in this article that the fundamental premise of CSSD is flawed, and that the premise has accordingly generated a dangerously unstable doctrinal structure which fobanns patched but did not repair. It is simply not true that First Amendment concerns are implicated whenever persons are required to subsidize speech with which they disagree. My thesis is that CSSD cannot be rebuilt along theoretically defensible lines until we have some better explanation of when

\footnotetext{
${ }^{10}$ Livestock Mktg., $335 \mathrm{~F} 3 \mathrm{~d}$ at $723 \mathrm{n} 9$. The court explained, "appellees in the present case are challenging the government's authority to compel them to support speech with which they personally disagree; such compulsion is a form of 'government interference with private speech.' The two categories of First Amendment cases--government speech cases and compelled speech cases-are fundamentally different." Id at 720.

"125 S Ct 2055 (2005).

${ }^{12}$ Id at 2062.

${ }^{13}$ Id at 2063.

${ }^{14}$ Id at 2062 (quoting Bd. of Regents $v$ Soutbworth, 529 US 217, 229 (2000)). In Keller v State Bar of California, 496 US 112-13 (1990), the Court was more explicit about the practical impossibility of extending the doctrinal structure of CSSD to include government speech:
}

Government officials are expected as a part of the democratic process to represent and to espouse the views of a majority of their constituents. . . . If every citizen were to have a right to insist that no one paid by public funds express a view with which he disagreed, debate over issues of great concern to the public would be limited to those in the private sector, and the process of government as we know it radically transformed. 
First Amendment review should be triggered and when it should not. Without such an explanation, the Court stands at risk of the kind of untoward consequences and embarrassing pirouettes that have afflicted its recent forays into this area.

\section{CSSD After Johanns}

In 1985 Congress enacted the Beef Promotion and Research Act, ${ }^{15}$ which announced that it was "in the public interest to authorize the establishment . . . of an orderly procedure for financing (through assessments on all cattle sold in the United States and on cattle, beef, and beef products imported into the United States) and [for] carrying out a coordinated program of promotion and research designed to strengthen the beef industry's position in the marketplace and to maintain and expand domestic and foreign markets and uses for beef and beef products." "Th The Act directed the Secretary of Agriculture to establish a "Cattlemen's Beef Promotion and Research Board," 17 whose members would "be cattle producers and importers appointed by the Secretary," ${ }^{18}$ and in particular to establish a Beef Promotion Operating Committee, which would be composed of ten Board members elected by the Board "and ten producers elected by a federation that includes as members the qualified State beef councils." 19 The function of the Committee was to "develop plans or projects of promotion and advertising, research, consumer information, and industry information, which shall be paid for with assessments collected by the Board."20

The Act provided that the promotional campaigns of the Committee and the Board were to be subject to the approval of the Secretary of Agriculture, and that they were to be supported by an excise tax, or "checkoff," on the sale or importation of cattle or on the importation of beef products. ${ }^{21}$ Since 1988 , "more than $\$ 1$ billion has been collected through the checkoff and a large fraction of that sum has been spent on promotional projects authorized by

\footnotetext{
157 USC $\$ \$ 2901-11(2000)$

${ }^{16} 7$ USC $\$ 2901(b)$.

177 USC $\$ 2904(1)$.

${ }^{18}$ Id.

197 USC $\$ 2904(4)(A)$.

${ }^{20} 7$ USC $\$ 2904(4)(B)$.

${ }^{21}$ Johanns, $125 \mathrm{~S} \mathrm{Ct}$ at 2058.
} 
the Beef Act-many using the familiar trademarked slogan 'Beef. It's What's for Dinner."'22

Two associations whose members paid the checkoff and several individuals who raised and sold cattle brought suit objecting to various statutory and constitutional aspects of the promotional program sponsored by the Beef Board and its Operating Committee. While their suit was pending, the Supreme Court decided United States $v$ United Foods, Inc., ${ }^{23}$ in which the Court, over the dissenting votes of Justices O'Connor, Ginsburg, and Breyer, upheld a challenge to the Mushroom Promotion, Research, and Consumer Information Act. ${ }^{24}$ The Act authorized the Secretary of Agriculture to create a Mushroom Council empowered to impose mandatory assessments on handlers of fresh mushrooms in order to serve the statute's goals of advancing projects of mushroom promotion, research, consumer information, and industry information. ${ }^{25}$ The Court concluded that requiring mushroom growers to subsidize a mushroom promotional campaign with which they disagreed violated their First Amendment rights.

The cattlemen amended their complaint to allege First Amendment violations of a similar nature. The Eighth Circuit concluded that " $[t]$ he beef checkoff program is, in all material respects, identical to the mushroom checkoff' at issue in United Foods." ${ }^{26}$ Although the Court in United Foods had pretermitted the claim that "the advertising here is government speech, and so immune from the scrutiny we would otherwise apply," ${ }^{27}$ the Eighth Circuit held that even on the assumption that the promotional programs sponsored by the Beef Board were government speech, compelled subsidization of the programs could be justified only if "the governmental interest in the commercial advertising under the Beef Act is sufficiently substantial to justify the infringement upon appellees' First Amendment right not to be compelled to subsidize that commercial

\footnotetext{
${ }^{22}$ Id at 2059 (citation omitted). The Eight Circuit found that at least $50 \%$ of the checkoff funds were used to support advertising planned by the Operating Committee. $335 \mathrm{~F} 3 \mathrm{~d}$ at 717.

${ }^{23} 533$ US 405 (2001).

${ }^{24} 7$ USC $\$ \$ 6101-12(2000)$.

257 USC $\$ 6104(c)(4)$.

${ }^{26} 335$ F3d at 717 (quoting Livestock Mktg. Ass'n v U.S. Dep't of Agric., 207 F Supp 2d 992, 1002 (DSD 2002)).

${ }^{27}$ United Foods, 533 US at 416 . The reason offered by the Court was that "this argument was 'not raised or addressed' in the Court of Appeals." Id.
} 
speech." ${ }^{28}$ Answering that inquiry in the negative, the Eighth Circuit ruled that the beef checkoff program established by the Beef Promotion and Research Act was unconstitutional on its face.

The Supreme Court reversed the Eighth Circuit in Fobanns $v$ Livestock Marketing Ass'n. ${ }^{29}$ The opinion for the Court was authored by Justice Scalia. It was joined by Chief Justice Rehnquist and by Justices O'Connor, Thomas, and Breyer. Scalia began his analysis by dividing "First Amendment challenges to allegedly compelled expression" ${ }^{30}$ into two categories. He distinguished "true 'compelled speech' cases, in which an individual is obliged personally to express a message he disagrees with, imposed by the government," "compelled subsidy' cases, in which an individual is required by the government to subsidize a message he disagrees with, expressed by a private entity." 32

Acknowledging that the Court in United Foods had struck down "an assessment very similar to the beef checkoff, imposed to fund mushroom advertising," 33 Scalia noted that United Foods had nevertheless rested "on the assumption that the advertising was private speech, not government speech." ${ }^{34}$ This assumption was decisive, because fobanns announced the categorical rule that individuals "have no First Amendment right not to fund government speech." 35 Scalia did not seek to explain this rule, except to observe that "[s]ome of our cases have justified compelled funding of government speech by pointing out that government speech is subject to democratic accountability." 36

$28335 \mathrm{~F} 3 \mathrm{~d}$ at 723 .

${ }^{29} 125$ S Ct 2055 (2005).

${ }^{30}$ Johanns, $125 \mathrm{~S} \mathrm{Ct}$ at 2060.

${ }^{31}$ Id.

${ }^{32}$ Id. In compelled subsidy cases "individuals are compelled not to speak, but to subsidize a private message with which they disagree." Id at 2060-61.

${ }^{33}$ Id at 2061.

${ }^{34} \mathrm{Id}$.

${ }^{35}$ Id at 2063.

${ }^{36}$ Id at 2064 . Scalia also noted in a footnote that the compelled subsidization of private speech violates the First Amendment "because being forced to fund someone else's private speech unconnected to any legitimate government purpose violates personal autonomy." Id at $2065 \mathrm{n} 8$. "Such a violation does not occur," Scalia continued, "when the exaction funds government speech." Id. This reasoning does not distinguish fobanns from United Foods, because the "government purpose" in United Foods was exactly the same as its purpose in fobanns: the stabilization and promotion of a market for American agricultural produce. The categorical distinction between being compelled to subsidize private speech and being 
The debate in fohanns was whether the advertisements sponsored by the beef checkoff program were in fact government speech. In the years after United Foods, lower courts had more or less come to the conclusion that the First Amendment did not prohibit the compulsory funding of government speech, ${ }^{37}$ and they had articulated an intricate jurisprudence to distinguish government from private speech. This jurisprudence asked two questions. The first focused on whether "the government nominally controls the production of advertisements, but as a practical matter has delegated control over the speech to a particular group that represents only one segment of the population." 38 The second focused on whether persons were compelled to fund government speech through general taxation or instead through "assessments levied on a particular group."

Jobanns flatly rejects both these factors. Even though the promotional campaigns of the Beef Board and its Operating Committee

compelled to subsidize government speech thus cannot be explained by the presence or absence of a legitimate government purpose.

${ }^{37}$ Most courts differed in this regard from the Eighth Circuit decision in Livestock Marketing. See text at note 10. For a classic statement, see R.F. Reynolds Tobacco Co. $v$ Sbewry, 384 F3d 1126, 1136 (9th Cir 2004).

${ }^{38}$ R.7. Reynolds, 384 F3d at 1136 . See, e.g., Pelts do Skins, LLC v Landreneau, 365 F3d 423, 431 ( 5 th Cir 2004) (holding that generic advertising authorized by the Louisiana Fur and Alligator Advisory Council is not government speech in part because the Council "reflects private rather than government interests"), vacated, $125 \mathrm{~S} \mathrm{Ct} 2511$ (2005); Cocbran $v$ Veneman, 359 F3d 263, 279 (3d Cir 2004) (holding that government speech doctrine does not apply to generic advertising by the National Dairy Promotion and Research Board because the "promotional programs" created by the Dairy Promotion Stabilization Act of 1983 are "special interest legislation on behalf of the industry's interest more so than the government's"), vacated sub nom, Lovell v Cocbran, $125 \mathrm{~S} \mathrm{Ct} 2511$ (2005), and Johanns v Cocbran, 125 S Ct 2512 (2005); Mich. Pork Producers Ass'n v Veneman, 348 F3d 157, 161 (6th Cir 2003) (“'T]he pork industry's extensive control over the Pork Act's promotional activities prevents their attribution to the government."), vacated sub nom, Mich. Pork Producers Ass'n v Campaign for Family Farms, 125 S Ct 2511 (2005), and Jobanns v Campaign for Family Farms, 125 S Ct 2511 (2005); In re Wash. State Apple Adver. Comm'n, 257 F Supp 2d 1274, 1281-82 (ED Wash 2003) (holding that government speech doctrine does not apply to generic advertising by the Washington State Apple Commission because "the Commission is not answerable to the State of Washington" and "the Government retains virtually no control over the Commission").

${ }^{39}$ Pelts \& Skins, 365 F3d at 430. See Mich. Pork Producers, 348 F3d 157, 161-62 (6th Cir 2003) ("TT]he Pork Act's promotion activities" are not government speech in part because, "unlike the typical scenario in which speech is considered governmental in nature, the programs' funding does not come from general tax revenues. . . . The Pork Act's funding comes solely from mandatory assessments paid by pork producers . . . ."); United States v Frame, 885 F2d 1119, 1132 (3d Cir 1989) ("When the government allocates money from the general tax fund to controversial projects or expressive activities, the nexus between the message and the individual is attenuated. In contrast, where the government requires a publicly identified group to contribute to a fund earmarked for the dissemination of a particular message associated with that group, the government has directly focused its coercive power for expressive purposes"). 
were supported by assessments levied specifically on beef producers, Johanns holds that the "First Amendment does not confer a right to pay one's taxes into the general fund, because the injury of compelled funding (as opposed to the injury of compelled speech) does not stem from the Government's mode of accounting." "And even though as a practical matter the Beef Board and its Operating Committee were deliberately designed to include the interests of the beef industry, Fohanns holds that "[w]hen, as here, the government sets the overall message to be communicated and approves every word that is disseminated, it is not precluded from relying on the government-speech doctrine merely because it solicits assistance from nongovernmental sources in developing specific messages." ${ }^{41}$ Fobanns also deems it irrelevant that the promotional campaign subsidized by the Beef Board and its Operating Committee never announced that it was sponsored by the government, and indeed that the campaign seemed to disguise that fact by producing advertisements which typically displayed "the attribution 'Funded by America's Beef Producers."'42

Fobanns holds that a First Amendment claim of compelled speech, as distinct from compelled subsidization of speech, would lie if the Beef Board's advertisements "were attributed" to individual plaintiffs. ${ }^{43}$ But such a claim of compelled speech could not be used to attack the Beef Promotion and Research Act on its face. At most it could be used to invalidate those particular applications of the Act in which specific plaintiffs could produce credible evidence that

${ }^{40} 125 \mathrm{~S} \mathrm{Ct}$ at 2063. "Apportioning the burden of funding government operations (including speech) through taxes and other levies does not violate autonomy simply because individual taxpayers feel 'singled out' or find the exaction 'galling." Id at $2065 \mathrm{n} 8$.

${ }^{41}$ Id at 2063 . "Here, the beef advertisements are subject to political safeguards more than adequate to set them apart from private messages. The program is authorized and the basic message prescribed by federal statute, and specific requirements for the promotions' content are imposed by federal regulations promulgated after notice and comment. The Secretary of Agriculture, a politically accountable official, oversees the program, appoints and dismisses the key personnel, and retains absolute veto power over the advertisements' content, right down to the wording. And Congress, of course, retains oversight authority, not to mention the ability to reform the program at any time. No more is required." Id at 2064.

${ }^{42}$ Id at 2059 (citation omitted). "[T]he correct focus is not on whether the ads' audience realizes the government is speaking, but on the compelled assessment's purported interference with respondents' First Amendment rights. As we hold today, respondents enjoy no right not to fund government speech-whether by broad-based taxes or targeted assessments, and whether or not the reasonable viewer would identify the speech as the government's." Id at $2064 \mathrm{n} 7$.

${ }^{43}$ Id at 2065 . 
Beef Board advertisements were actually attributed to them. The Court could see no such evidence in the record.

Justice Thomas joined Scalia's opinion for the Court, but he wrote separately to emphasize his continuing allegiance to what he regarded as the fundamental premise of United Foods, which was "that " $[a] n y$ regulation that compels the funding of advertising must be subjected to the most stringent First Amendment scrutiny." 44 Thomas, like Scalia, did not explain why this principle did not apply to compelled funding of government speech. ${ }^{45} \mathrm{He}$ pointed only to the brute practicalities of the situation: "I recognize that this principle must be qualified where the regulation compels the funding of speech that is the government's own. It cannot be that all taxpayers have a First Amendment objection to taxpayer-funded government speech, even if the funded speech is not 'germane' to some broader regulatory program. ${ }^{\$ 46}$

Justice Breyer also authored a separate opinion. He had dissented in United Foods on the grounds "that the challenged assessments involved a form of economic regulation, not speech." ${ }^{\text {"47 }}$ Breyer joined the opinion of the Court in Fobanns " $[\mathrm{w}]$ ith the caveat that I continue to believe that my dissent in United Foods offers a preferable approach." ${ }^{48}$ Justice Ginsburg concurred in the judgment of the Court. Although she refused to credit that the advertisements funded by the checkoff program were "government speech," because they were not "attributed to the Government," ${ }^{49}$ she nevertheless continued to maintain, as she had in United Foods, that "the assessments in

\footnotetext{
${ }^{44}$ Id at 2066 (Thomas, J, concurring) (quoting United Foods, 533 US 405, 419 (2001) (Thomas, J, concurring)).

${ }^{45}$ Thomas did note that " $[t]$ he payment of taxes to the government for purposes of supporting government speech is not nearly as intrusive as being forced to 'utter what is not in [one's] mind,' or to carry an unwanted message on one's property." Id at 2067 (quoting W. Va. Bd. of Ed. v Barnette, 319 US 624, 634 (1942)). But of course this line of thought would seem to suggest that in each case of subsidized speech, the presence or absence of First Amendment concerns would depend upon the extent of intrusion created by the precise method of subsidization. This would in turn undermine what Thomas evidently regarded as the fundamental premise of United Foods, which was that the compelled funding of speech always raised First Amendment concerns.

${ }^{46}$ Id at 2066. Thomas also stressed that " $[t]$ he government may not, consistent with the First Amendment, associate individuals or organizations involuntarily with speech by attributing an unwanted message to them, whether or not those individuals fund the speech, and whether or not the message is under the government's control." Id.

${ }^{47}$ Id at 2067 (Breyer, J, concurring).

${ }^{48}$ Id.

${ }^{49}$ Id at 2067 (Ginsburg, J, concurring in the judgment).
} 
these cases . . qualify as permissible economic regulation." ${ }^{50}$

Justice Souter authored the principal dissent; he was joined by Stevens and Kennedy. He began with the premise that the facts of fohanns were "on all fours with United Foods," 51 which had struck down the Mushroom Promotion, Research, and Consumer Information Act because it "violated the growers' First Amendment right to refuse to pay for expression when they object to its content." Souter agreed with the Court that there was a "need to recognize the legitimacy of government's power to speak despite objections by dissenters whose taxes or other exactions necessarily go in some measure to putting the offensive message forward to be heard." ${ }^{53}$ But he argued that on the facts of Fobanns the advertisements of the Beef Board and its Operating Committee ought not to be considered government speech.

Souter's argument is complex and not entirely transparent, but its gist is that infringements of the "presumptive autonomy" ${ }^{54}$ protected by the First Amendment against compelled subsidization of speech must be evaluated not only in light of the state's interest in requiring subsidization, ${ }^{55}$ but also with an eye to the precise forms of subsidization exacted by the state and to the mechanisms that could potentially serve as "an effective political check on forced funding for speech." ${ }^{56}$ Souter contrasted government speech supported by revenues secured through general taxation with government speech supported by revenues secured through narrowly targeted assessments, like those at issue in fobanns:

[W] hen government funds its speech with general tax revenue, as it usually does, no individual taxpayer or group of taxpayers can lay claim to a special, or even a particularly strong, connection to the money spent (and hence to the speech funded). Outrage is likely to be rare, and disagreement tends to stay temperate.

\footnotetext{
${ }^{50} \mathrm{Id}$ at 2068.
}

${ }^{51}$ Id at 2070 (Souter, J, dissenting).

52 Id at 2069.

${ }^{53}$ Id at 2070. Souter, like the other Justices who considered the question, seemed to conceive the relationship between government speech and CSSD in terms of sheer practical necessity. "To govern, government has to say something, and a First Amendment heckler's veto of any forced contribution to raising the government's voice in the 'marketplace of ideas' would be out of the question." Id.

${ }^{54}$ Id at 2071.

${ }^{55}$ Souter interprets United Foods as prohibiting "compelled subsidy of speech . . . absent a comprehensive regulatory scheme to which the speech was incidental." Id at 2068.

${ }^{56} \mathrm{Id}$ at 2073 n 8. 
But the relative palatability of a remote subsidy shared by every taxpayer is not to be found when the speech is funded with targeted taxes. For then, as here, the particular interests of those singled out to pay the tax are closely linked with the expression, and taxpayers who disagree with it suffer a more acute limitation on their presumptive autonomy as speakers to decide what to say and what to pay for others to say. ${ }^{57}$

Souter's basic point is that the "autonomy" of persons to refuse to fund speech with which they disagree grows more compromised as the link between the subsidy and the speech becomes closer and more direct. ${ }^{58}$ Speech supported by "a targeted assessment . . . makes the First Amendment affront more galling." ${ }^{59}$ In such circumstances "greater care is required to assure that the political

\footnotetext{
${ }^{57}$ Id at 2071 (citation omitted).

${ }^{58}$ Seventeen years ago the Third Circuit, considering the same statute as that at issue in Fobanns, articulated this basic idea in terms of what it called a "coerced nexus" test:
}

\begin{abstract}
Both the right to be free from compelled expressive association and the right to be free from compelled affirmation of belief presuppose a coerced nexus between the individual and the specific expressive activity. When the government allocates money from the general tax fund to controversial projects or expressive activities, the nexus between the message and the individual is attenuated. In contrast, where the government requires a publicly identified group to contribute to a fund earmarked for the dissemination of a particular message associated with that group, the government has directly focused its coercive power for expressive purposes. This sort of funding scheme, with its close nexus between the individual and the message funded, more closely resembles the Abood situation, where the unions, as exclusive bargaining agents, served as the locutors for a distinguishable segment of the population, i.e., the employees, or the Wooley case, where the state "require[d] an individual to participate in the dissemination of an ideological message by displaying it on his property in a manner and for the express purpose that it be observed and read by the public," regardless of whether the state-issued license plates constituted "government speech."
\end{abstract}

United States v Frame, 885 F2d 1119, 1132-33 (3d Cir 1989) (citations omitted) (quoting Wooley v Maynard, 430 US 705, 713 (1977)). The coerced nexus test was influential among lower courts. See, e.g., Pelts \& Skins, LLC v Landreneau, 365 F3d 423 (5th Cir 2004), vacated, 125 S Ct 2511 (2005); Cal-Almond, Inc. v Calif. Dept. of Agric., 14 F3d 429, 435 (9th Cir 1993); Summit Med. Ctr of Ala., Inc. v Riley, 284 F Supp 2d 1350, 1360-61 (MD Ala 2003). See also Forum for Academic and Institutional Rights $v$ Rumsfeld, 390 F3d 219, 259 (3d Cir 2004); R.7. Reynolds Tobacco Co. v Shezvry, 384 F3d 1126, 1149 (9th Cir 2004) (Trott, J, dissenting).

${ }^{50}$ Fobanns, $125 \mathrm{~S} \mathrm{Ct}$ at 2071 . Souter invokes "the commonsense notion that individuals feel a closer connection to speech that they are singled out to fund with targeted taxes than they do to expression paid for with general revenues. We recognized this in Massacbusetts $v$ Mellon, 262 US 447 (1923), where we noted that the individual taxpayer's 'interest in the moneys of the Treasury-partly realized from taxation and partly from other sources-is shared with millions of others [and] is comparatively minute and indeterminable.' Id. at 487 . This commonsense notion, then, provides a 'principled way' to distinguish in this context between targeted and general taxes." Id at $2071 \mathrm{n} 4$. 
process can practically respond to limit the compulsion . . .."60

Souter conceives political accountability as ensuring "that government is not untouchable when its speech rubs against the First Amendment interests of those who object to supporting it; if enough voters disagree with what government says, the next election will cancel the message." "[T]he requirement of effective public accountability" is not met in fobanns, Souter argues, because "the Beef Act does not establish an advertising scheme subject to effective democratic checks. . . . [T]he ads are not required to show any sign of being speech by the Government, and experience under the Act demonstrates how effectively the Government has masked its role in producing the ads." 22 Souter thus concludes that the government speech exception to CSSD ought not to apply in fohanns: "[E]xpression that is not ostensibly governmental, which government is not required to embrace as publicly as it speaks, cannot constitute government speech sufficient to justify enforcement of a targeted subsidy to broadcast it." ${ }^{63}$

The exact function of political accountability in Souter's dissent is obscure. Souter writes as if accountability were necessary to check government taxation from becoming too violently inconsistent with the First Amendment interests of those forced to subsidize government speech. But why political accountability would perform this function is never explained. It is true that we can expect voters to cancel messages that they dislike, but voters have no particular reason to cancel those messages that especially violate the autonomy of taxpayers. It may be that cattlemen deeply object to, and find

\footnotetext{
${ }^{60} \mathrm{Id}$ at 2071-72 (Souter, J, dissenting). Such scrutiny would be practical, Souter argues, because " $[w]$ hereas it would simply be unrealistic to think that every speech subsidy from general revenue could or should be scrutinized for its amenability to effective political response, the less-common targeted speech subsidies can be reviewed specifically for their susceptibility to response by the voters, and the intensity of the provocation experienced by the targeted group justifies just such scrutiny." Id at 2072 .

${ }^{61}$ Id at 2071.

${ }^{62}$ Id at 2072. "It means nothing," Souter writes, "that Government officials control the message if that fact is never required to be made apparent to those who get the message, let alone if it is affirmatively concealed from them. The political accountability of the officials with control is insufficient, in other words, just because those officials are allowed to use their control (and in fact are deliberately using it) to conceal their role from the voters with the power to hold them accountable." Id at 2073.

${ }^{63}$ Id at 2073-74. Justice Kennedy in Johanns filed a short separate opinion to note that he would "reserve for another day the difficult First Amendment questions that would arise if the government were to target a discrete group of citizens to pay even for speech that the government does "embrace as publicly as it speaks." Id at 2068 (Kennedy, J, dissenting).
} 
especially galling, a message that is quite popular with voters. Public approval of a message does not seem a plausible candidate for a mechanism to prevent the abuse of the autonomy of targeted taxpayers. ${ }^{64}$

Souter proposes that the First Amendment interest protected by CSSD is the "autonomy" not to be connected through the medium of money to speech to which one objects. Souter invokes the "commonsense notion" that this "connection" can be "closer" or less close ${ }^{66}$ depending upon the directness of the relationship between the subsidy and the speech it funds. As the connection grows closer, the violation of First Amendment autonomy grows greater; as the connection becomes more distant, the violation diminishes in significance. That is why for Souter the doctrinal notion of "government speech" is at most a label used to express the outcome of a detailed process of constitutional analysis and balancing. Souter's dissent is in fact carefully written to avoid the implication that "government speech" is a categorical exception to CSSD. Souter asks only whether the interests served by a particular instance of "government speech" are "sufficient to justify enforcement of a targeted subsidy to broadcast it." ${ }^{\prime 67}$

In contrast, Scalia's majority opinion conceives "government speech" as a distinct category of expression that obliterates whatever First Amendment interest persons may have in not being required to subsidize the speech of others. Although Scalia apparently agrees with Souter that the underlying constitutional interest at stake is

${ }^{64} \mathrm{I}$ do not mean to deny, of course, that there may be circumstances in which First Amendment jurisprudence should care very deeply about political accountability. The Constitution ought to be concerned, for example, about the distortions potentially inflicted upon the marketplace of ideas whenever the government enters public debate by stealth, as apparently occurred when the Department of Health and Human Services packaged video segments promoting a Medicare bill to look like news reports and paid to broadcast them during local news telecasts, or when the Department of Education paid the columnist Armstrong Williams to promote the No Child Left Behind Act in his capacity as a television pundit. See generally Clay Calvert, Payola, Pundits, and the Press: Weighing the Pros and Cons of FCC Regulation, 13 Commlaw Conspectus 245 (2005); Gregory Klass, The Very Idea of a First Amendment Right Against Compelled Subsidization, 38 UC Davis L Rev 1087, 1128-29 (2005). But the constitutional issues raised by government stealth do not depend upon whether government speech is funded by a general tax or by targeted assessments. These issues are structural and do not involve the "autonomy" First Amendment rights of individual taxpayers.

${ }^{65}$ See text at note 57.

${ }^{66}$ See note 59 above.

${ }^{67}$ Jobanns, $125 \mathrm{~S} \mathrm{Ct}$ at 2073 (Souter, J, dissenting). 
one of "personal autonomy," ${ }^{8}$ he conceptualizes the "government speech" exception to CSSD as categorical and without qualifications of degree. ${ }^{69}$ A First Amendment question is presented if persons are compelled to support the speech of a private individual, but not if persons are taxed, whether by a general tax or by a targeted assessment, to support the speech of the government. Scalia's approach seems to advance a clear and forceful rule, but it actually renders quite mysterious the nature of the First Amendment interests that CSSD aspires to protect. Exactly what kind of interests would require stringent First Amendment scrutiny to prevent the compelled subsidization of the expression of private parties, but no scrutiny at all to prevent the compelled subsidization of government speech?

The strangely dichotomous character of the First Amendment interests presupposed by Scalia is especially puzzling because we know that the First Amendment interests of persons in what Scalia at the outset of his opinion calls "true 'compelled speech' cases"70 do not disappear when persons are compelled to express the message of the government. Scalia cites two compelled speech cases: West Virginia Board of Education v Barnette ${ }^{71}$ in which schoolchildren were required to recite the Pledge of Allegiance, the text of which was set out by state regulation, and Wooley $v$ Maynard, ${ }^{72}$ in which George Maynard, a Jehovah's witness, was required to display the state motto of New Hampshire on the prefabricated license plate of his automobile. In each case the relevant message was composed by the government. In each case the First Amendment was interpreted to protect a right "to refrain from speaking at all,"73 and in each case it did not matter whether the message whose utterance was compelled was that of the government or that of a private party.

Johanns itself establishes that there is no "government speech" exception to claims of compelled speech, for it holds that plaintiffs' allegation of compelled speech can succeed if they are able to prove

\footnotetext{
${ }^{68}$ See notes 36 and 40.

${ }^{69}$ Scalia never explains why autonomy interests cannot be more or less violated, depending upon the closeness of the connection between the subsidy and the speech.

${ }^{70} 125 \mathrm{~S} \mathrm{Ct}$ at 2060.

${ }^{71} 319$ US 624 (1943).

72430 US 705 (1977).

${ }^{73}$ Wooley, 430 US at 714. See Barnette, 319 US at 634 ("[A] Bill of Rights which guards the individual's right to speak his own mind" does not leave it "open to public authorities to compel him to utter what is not in his mind.").
} 
on remand that the Beef Board's advertisements were "attributed" to them individually. ${ }^{74}$ Because Fobanns holds that these advertisements are government speech, the Court necessarily concludes that plaintiffs have First Amendment interests in not being compelled to express government speech. But surely it is puzzling that First Amendment interests in not being compelled to speak are indifferent to whether the compelled speech is governmental or private, whereas First Amendment interests in not being compelled to subsidize speech depend entirely upon this distinction. Why should this be so?

What renders the question particularly disturbing is that Scalia's distinction between compelled speech cases and compelled subsidy cases is itself highly uncertain. In Wooley, for example, nobody could plausibly have imagined that George Maynard was actually speaking through the prefabricated license plate he was forced to display. Indeed (then) Justice Rehnquist dissented in Wooley, asking why there was "any 'speech' or 'speaking' in the context of this case. . . . The issue, unconfronted by the Court, is whether appellees, in displaying, as they are required to do, state license tags, the format of which is known to all as having been prescribed by the State, would be considered to be advocating political or ideological views." ${ }^{75}$

The Court could not respond to Rehnquist's challenge; it could only vaguely mutter that "compelling the affirmative act of a flag salute [in Barnette] involved a more serious infringement upon personal liberties than the passive act of carrying the state motto on a license plate, but the difference is essentially one of degree." Wooley tells us that:

Here, as in Barnette, we are faced with a state measure which forces an individual, as part of his daily life indeed constantly while his automobile is in public view to be an instrument for fostering public adherence to an ideological point of view he finds unacceptable. . . . New Hampshire's statute in effect requires that appellees use their private property as a "mobile billboard" for the State's ideological message or suffer a penalty, as Maynard already has. ${ }^{76}$

Having one's car transformed into a "mobile billboard" for state

${ }^{74}$ Jobanns, $125 \mathrm{~S} \mathrm{Ct}$ at 2065.

${ }^{75}$ Wooley, 430 US at 720-21 (Rehnquist, J, dissenting).

${ }^{76}$ Id at 715. 
messages is not precisely the same as being forced to speak. It is more like being forced to allow one's car to be used as a platform for the state to speak. This suggests that Wooley is not so much about George Maynard's First Amendment interest in not being forced to speak as it is about his First Amendment interest in not having his property appropriated to subsidize government speech. But fobanns seems to hold that this interest does not exist.

Souter's dissenting opinion is by contrast free from such internal tensions. He begins with the premise that a First Amendment autonomy interest is compromised whenever persons are required to subsidize speech with which they disagree, and he applies this premise to the context of government speech. Souter postulates that government speech subsidized by general taxation so minimally affects this autonomy interest as to be beyond judicial protection. But he concludes that this interest remains vivid and enforceable in the context of government speech supported by targeted assessments. This logic is faithful to the structure of CSSD as set forth in United Foods. The difficulty, however, is that Souter's dissent is based upon a false premise.

\section{The Theoretical Foundations of CSSD}

Consider the case of Banning $v$ Newdow, ${ }^{77}$ in which Michael Newdow, the same prickly pro se litigant who challenged the constitutionality of the Pledge of Allegiance, ${ }^{78}$ was involved in an "ongoing child custody proceeding." 79 Newdow objected to an order "to pay a portion of the attorney's fees of the child's mother." ${ }^{80} \mathrm{He}$ advanced the argument, which no doubt would be unthinkable to a trained lawyer, that the order was unconstitutional because of CSSD. Newdow contended that requiring him to pay the attorneys' fees of his opponent was to compel him directly to subsidize expression with which he disagreed. Because the speech of the opposing attorney was private, Newdow's argument is not affected by the holding of fobanns, which purports to leave in place the doctrinal structure of CSSD that was established in United Foods.

Newdow's innovative argument should make us pause, because,

\footnotetext{
714 Cal Rptr 3d 447 (Ct App 2004).

${ }^{78}$ Elk Grove Unified Sch. Dist. v Newdow, 542 US 1 (2004).

${ }^{79}$ Banning, 14 Cal Rptr 3d at 449.

${ }^{80} \mathrm{Id}$.
} 
in a literal sense, all statutes awarding attorneys' fees force "certain individuals to pay subsidies for speech to which they object." ter's dissent in fobanns postulates an intrinsic "autonomy" interest in not being forced to pay for the speech of another, and it conceptualizes the strength of this interest as dependent upon the closeness of the connection between the subsidy and the speech it supports. We should note, therefore, that in Newdow's case this connection is as close and as direct as it is possible to be. And of course Newdow vigorously disagrees with the speech that he is forced to subsidize, for it is the expression of his opponent in litigation.

The logic of CSSD would thus support Newdow's position. Although that logic does not establish whether any particular attorneys' fees statute is constitutional or unconstitutional, it does raise the question of whether all such statutes must be given careful First Amendment attention. ${ }^{82}$ Newdow's argument forces us to ask whether we should regard all attorneys' fees statutes as raising constitutional concerns that need to be adjudicated on a statute-bystatute basis. ${ }^{83}$

The Newdow case is only the tip of the iceberg, for there are many ordinary situations in which government compels persons directly to pay for the speech of third parties. Consider, for example, the requirement that cars can be registered only if mechanics are

\footnotetext{
${ }^{81}$ United States $v$ United Foods, Inc., 533 US 405, 410 (2001).

${ }^{82}$ To invoke a distinction that is associated with the work of Frederick Schauer, we must in such cases distinguish between First Amendment "coverage," which requires "that the constitutionality of [a] regulation must be determined by reference to First Amendment doctrine and analysis," and First Amendment "protection," which implies that the First Amendment renders a particular regulation unconstitutional. Robert Post, Encryption Source Code and the First Amendment, 15 Berkeley Tech L J 713, 714 (2000). See Frederick Schauer, The Boundaries of the First Amendment: A Preliminary Exploration of Constitutional Salience, 117 Harv L Rev 1765, 1769-72 (2004). CSSD is above all a doctrine that is designed to define the scope of First Amendment coverage, as distinct from First Amendment protection. In fact both the Court and Souter have been notably reluctant to specify a test for First Amendment protection. See, e.g., United Foods, 533 US at 410; Jobanns, $125 \mathrm{~S} \mathrm{Ct}$ at $2074 \mathrm{n} 10$ (Souter, J, dissenting).

${ }^{83}$ The court in Newdow knew that it had to reject Newdow's claim, but it didn't know quite how to do so, and as a consequence it could only sputter that CSSD is not relevant unless the "only purpose" of "compelled assessments" is "to support the offensive speech. . . . Here the purpose of the fee award is to ensure that a child's best interests are represented." Banning, 14 Cal Rptr 3d at 449. The problem with this reasoning is that it misrepresents United Foods, in which the federal government had imposed targeted assessments in order to stabilize and promote the market for mushrooms, just as the targeted assessments in Fobanns were for the purpose of stabilizing and promoting the market for beef. It will be a rare case indeed in which the state compels speech for no reason at all.
} 
paid to certify that they meet smog emission standards. ${ }^{84}$ Consider the requirement that children can be enrolled in public school only if physicians are paid to certify their immunization records. ${ }^{85} \mathrm{Or}$ consider the requirement that publicly owned businesses pay for the financial reports of independent accountants. ${ }^{86} \mathrm{We}$ must decide whether these everyday government regulations have all along posed deep, unrecognized First Amendment issues, or whether, like the government speech at issue in Fobanns, they do not present any constitutional question at all. ${ }^{87}$

These examples suggest that there are strong reasons to conclude that First Amendment concerns are not always triggered whenever persons are forced to subsidize the speech of a third party. This conclusion would render CSSD consistent with First Amendment

${ }^{84}$ Forced to conduct emissions inspections by federal clean-air rules, many states have outsourced their inspection duties by relying on a "decentralized network [that] uses gasoline stations or repair facilities as test centers." See Arnold W. Reitze, Jr., Air Quality Protection Using State Implementation Plans: Thirty-Seven Years of Increasing Complexity, 15 Vill Envtl L J 209, 265 (2004).

${ }^{85}$ See, e.g., Ariz Rev Stat Ann $\$ 15-872$ (2002) ("A pupil [unless exempted] shall not be allowed to attend school without submitting documentary proof [of vaccination] to the school administrator . . .."); Ark Code Ann $\$ 6-18-702$ (1999) (conditioning attendance in school on multiple vaccinations "as evidenced by a certificate of a licensed physician or a public health department acknowledging the immunization"); La Rev Stat Ann $\$ 17$ : 170 (2001); NH Rev Stat Ann \$141-C:20 (1996); Conn Agencies Regs \$ 10-204a-2a (2000); NM Code R $\$ 6.12 .2 .1-.11$ (Weil 2001). See generally James G. Hodge, Jr., and Lawrence O. Gostin, School Vaccination Requirements: Historical, Social and Legal Perspectives, $90 \mathrm{Ky} \mathrm{L} \mathrm{J} \mathrm{831,} 833$ (2001-2002) (summarizing state laws and stating that "modern state school vaccination laws mandate that children be vaccinated prior to being allowed to attend public or private schools. Failure to vaccinate children can result in children being denied from attending school, civil fines and criminal penalties . . . ").

${ }^{86}$ See, e.g., Securities Act of 1933, 15 USC $\$ 77 \mathrm{aa}(25)$ sched A (2000) (requiring that balance sheets and profit and loss statements included in registration statements be certified by an independent accountant); Securities Exchange Act of 1934, 15 USC $\S 78 \mathrm{~m}(\mathrm{a})(2)$ (2000) (authorizing the SEC to require that financial statements included in annual reports be certified by an independent accountant).

${ }^{87}$ It might be said that some of these situations do not implicate CSSD because the First Amendment is triggered only when government compels "certain individuals to pay subsidies for speech to wbich they object." United Foods, 533 US at 410 (emphasis added). We do not object, so the argument might run, to a mechanic's certification that our car meets smog emission requirements, or to a physician's certification that our child meets immunization requirements. But this argument misses the point that the mechanic or the physician may at least initially give us bad news and communicate to us that our car has failed to meet emission requirements or that our child requires yet another vaccination. We may vigorously disagree with this speech, but the government will nevertheless have effectively forced us to pay for it, on pain of not driving our car or not enrolling our children in public school. The question is whether this potential disagreement should raise a First Amendment problem for these statutes. I pass over the example of required financial statements, because I assume that if a CPA is performing her job with proper professional independence her financial statements will routinely contain assertions to which her client might object. 
jurisprudence generally, because First Amendment concerns are not automatically activated whenever expression is restricted ${ }^{88} \mathrm{I}$ have argued the point at length elsewhere and will not repeat those arguments here. ${ }^{89}$ Suffice it to note that because speech and expression are intrinsic to all human conduct, the regulation of conduct inevitably involves the regulation of the communication that defines the conduct. If virtually every regulation of conduct became a constitutional question, the First Amendment would rapidly become unworkable. For this reason, our First Amendment is not triggered whenever communication is regulated; we do not have a First Amendment jurisprudence of contracts, even though contracts subsist entirely within the realm of expression. ${ }^{90}$ Constitutional review is triggered only when communication is regulated in a manner that implicates specific First Amendment values. As I have argued elsewhere, these values most conspicuously include democratic selfgovernance and participation in the construction of public opinion. $^{91}$

Just as the First Amendment is not triggered by all restrictions on speech, so the First Amendment is not triggered by all government compulsions to speak. In fact we experience such compulsions all the time, and no one regards them as raising constitutional issues. Examples range from compulsory jury service, ${ }^{92}$ to compulsory testimony before courts and legislatures, ${ }^{93}$ to compulsory reporting of

\footnotetext{
${ }^{88}$ Schauer at $1769-86$ (cited in note 82 ).

${ }^{89}$ Robert Post, The Constitutional Status of Commercial Speech, 48 UCLA L Rev 1, 9-10 (2000); Robert Post, Recuperating First Amendment Doctrine, 47 Stan L Rev 1249, 1254-55 (1995).

${ }^{90}$ Consistent with his dissent in fobanns and his acceptance of the major premise of CSSD, Justice Souter has advocated that First Amendment protections should attach to "speech as such." Glickman v Wileman Bros. \& Elliott, 521 US 457, 478 (1997) (Souter, J, dissenting). I cannot believe, however, that Souter would want plenary constitutional review of contract law.

${ }^{91}$ See note 89 above.

${ }^{92}$ See, e.g., 28 USC $\$ 1861$ (2000) ("It is further the policy of the United States that all citizens shall ... have an obligation to serve as jurors when summoned for that purpose."); Nancy J. King, 7uror Delinquency in Criminal Trials in America, 1796-1996, 94 Mich L Rev 2673, 2683 ("Fining those who failed to obey [jury] summonses [was] a universal response to jury dodging throughout the colonial period, and in the early $1800 \mathrm{~s}$ ....").

${ }^{93}$ On numerous occasions the Supreme Court has found it to be "beyond controversy that one of the duties which the citizen owes to his government is to support the administration of justice by attending its courts and giving his testimony whenever he is properly summoned." Blackmer $v$ United States, 284 US 421, 438 (1932). Thus the Court has reaffirmed that "neither the First Amendment nor any other constitutional provision protects
} 
vehicle accidents, ${ }^{94}$ to compulsory reporting of potential public health risks like those involving child abuse, ${ }^{95}$ to the myriad of public disclosures required by securities regulation, ${ }^{96}$ to the labeling requirements routinely required on consumer products. ${ }^{97}$ The very Beef Promotion and Research Act considered by fohanns provides

the average citizen from disclosing to a grand jury information that he has received in confidence." Branzburg v Hayes, 408 US 665, 682 (1972).

${ }^{94}$ Most states require drivers to report their involvement in traffic accidents that have resulted in injury or significant property damage. See, e.g., Cal Veh Code $\$ 20002$ (West 2005); NY Veh \& Traf Law $\$ 605$ (McKinney 2005). While the Supreme Court has never entertained a compelled speech challenge to these statutes, in Califormia v Byers, 402 US 424 (1971), the Court rejected the claim that such hit-and-run laws violate the Fifth Amendment privilege against self-incrimination, explaining that:

An organized society imposes many burdens on its constituents. It commands the filing of tax returns for income; it requires producers and distributors of consumer goods to file informational reports on the manufacturing process and the content of products, on the wages, hours, and working conditions of employees. Those who borrow money on the public market or issue securities for sale to the public must file various information reports; industries must report periodically the volume and content of pollutants discharged into our waters and atmosphere. Comparable examples are legion.

Id at 427-28. Mandatory reporting laws of these kinds have never been thought to raise First Amendment concerns.

${ }^{95}$ Virtually every state has some version of a mandatory reporting law to cover cases of child abuse. See Mason P. Thomas, Jr., Child Abuse and Neglect (pt 1), 50 NC L Rev 293, 332 (1972). Some states have extended the duty to report abuse to other areas, as for example by making the "[f]ailure to report elder mistreatment to public authorities . . . typically a criminal offense." Seymour Moskowitz, Saving Granny from the Wolf: Elder Abuse and Neglect-The Legal Framework, 31 Conn L Rev 77, 117 (1998).

${ }^{96}$ See Troy A. Paredes, Blinded by the Light: Information Overload and Its Consequences for Securities Regulation, 81 Wash U L Q 417, 427 (2003) ("Disclosure is the SEC's chief regulatory tool.").

${ }^{97}$ Just to offer some few examples enforced by the FTC, the Fair Packaging and Labeling Act, 15 USC $\$ \$ 1451-61(2000)$, directs the FTC to issue regulations requiring that all consumer commodities other than food, drugs, therapeutic devices, and cosmetics be labeled to disclose net contents, identity of commodity, and name and place of business of the product's manufacturer, packer, or distributor; the Truth in Lending Act, 15 USC $\$ \$ 1601-1667 \mathrm{f}(2000)$, requires all creditors who deal with consumers to make certain written disclosures concerning all finance charges and related aspects of credit transactions (including disclosing finance charges expressed as an annual percentage rate); the Wool Products Labeling Act, 15 USC $\$ \$ 68-68 j$ (2000), requires (1) that wool product labels indicate the country in which the product was processed or manufactured, and (2) that mail order promotional materials clearly and conspicuously state whether a wool product was processed or manufactured in the United States or was imported; the Fur Products Labeling Act, 15 USC $\$ 69-69 j$ (2000), requires that articles of apparel made of fur be labeled, and that invoices and advertising for furs and fur products specify, among other things, the true English name of the animal from which the fur was taken, and whether the fur is dyed or used; the Textile Products Identification Act, 15 USC $\$ 70-70 \mathrm{k}(2000)$, requires (1) that any textile fiber product processed or manufactured in the United States be so identified, and (2) that mail order promotional materials clearly and conspicuously indicate whether a textile fiber product was processed or manufactured in the United States or was imported. 
that marketers and importers of beef and cattle shall "maintain and make available for inspection such books and records as may be required by the order and file reports at the time, in the manner, and having the content prescribed by" ${ }^{98}$ a "beef promotion and research order" issued by the Secretary of Agriculture. ${ }^{99}$

There are thus innumerable circumstances in which the state forces persons to speak without raising First Amendment concerns. ${ }^{100}$ If speech can be compelled without triggering constitutional scrutiny, a fortiori the subsidization of speech can be required without raising First Amendment concerns. The First Amendment interest in not being compelled to subsidize particular speech derives from the First Amendment interest in not being compelled to express that particular speech. Hence if the state can compel a person to speak without triggering First Amendment scrutiny, it can also force that person to pay for the speech. Because speaking generally consumes resources, the compulsion to speak is often simultaneously the compulsion to subsidize speech. It would in such circumstances be strange indeed to hold that requiring a person to speak does not raise First Amendment concerns, but requiring him

${ }^{98} 7$ USC $\$ 2904(11)(2000)$.

${ }^{99} 7$ USC $\$ 2903$ (b) (2000).

${ }^{100}$ This conclusion is confirmed by the Court's recent decision in Rumsfeld $v$ Forum for Academic and Institutional Rigbts, 2006 WL 521237 (US March 6, 2006). The Court evaluated the argument of law schools that the so-called Solomon Amendment, which required law schools to provide access to military recruiters, was an unconstitutional violation of the First Amendment because it compelled law schools to speak, as for example by sending out announcements about the time and place at which students could meet military recruiters. The Court unanimously held that compelling such speech did not raise a First Amendment question:

There is nothing in this case approaching a Government-mandated pledge or motto that the school must endorse.

The compelled speech to which the law schools point is plainly incidental to the Solomon Amendment's regulation of conduct, and "it has never been deemed an abridgment of freedom of speech or press to make a course of conduct illegal merely because the conduct was in part initiated, evidenced, or carried out by means of language, either spoken, written, or printed." . . . Compelling a law school that sends scheduling e-mails for other recruiters to send one for a military recruiter is simply not the same as forcing a student to pledge allegiance, or forcing a Jehovah's Witness to display the motto "Live Free or Die," and it trivializes the freedom protected in Barnette and Wooley to suggest that it is.

Although the Court attempts to use the old and ultimately circular difference between speech and conduct to explain the distinction between compelled speech that raises a First Amendment question and compelled speech that does not raise a First Amendment question, for our purposes it is enough to notice that the Court does feel compelled to introduce and defend some such distinction. The Court plainly understands that a serious First Amendment question is not raised by every instance of compelled speech. 
to expend the resources for that speech does. The inevitable conclusion is that the compelled subsidization of speech does not by itself trigger First Amendment scrutiny.

CSSD, however, focuses specifically on the subsidization of objectionable speech. United Foods asserts that "First Amendment concerns apply" whenever the state requires persons to "subsidize speech with which they disagree." that because First Amendment scrutiny should be triggered whenever a person is forced to speak in ways that she finds objectionable, First Amendment review ought also to be triggered whenever a person is forced to subsidize speech she finds objectionable. But the premise of this reasoning is false. First Amendment concerns are not automatically aroused when persons are forced to speak in ways that they find objectionable. Persons may experience as personally "galling" 102 their obligation to testify before a court or a legislature; they may wish to refuse to pronounce a verdict as a juror; they may object to their responsibility to report a traffic accident; or they may find it repulsive to report an incident of child abuse. But in all these situations we nevertheless compel persons to speak without ever raising a First Amendment eyebrow.

We also compel persons to speak in ways that they believe to be flatly incorrect. High administration officials must mouth official administration positions, whether they believe them or not, and the First Amendment will offer no solace if they are fired for voicing their actual beliefs. ${ }^{103}$ Every day in state bureaucracies around the nation, government employees are required to draft memoranda setting forth positions with which they privately disagree. ${ }^{104} \mathrm{We}$ require corporations to file independent financial statements, even if they happen to disagree with the judgments made by their ac-

\footnotetext{
${ }^{101}$ United States $v$ United Foods, Inc., 533 US 405, 410-11 (2001).

${ }^{102}$ See Johanns, $125 \mathrm{~S} \mathrm{Ct}$ at 2071 (Souter, J, dissenting).

${ }^{103}$ See, e.g., Wilbur v Maban, 3 F3d 214, 215 (7th Cir 1993); Snyder v Blagojevich, 332 F Supp 2d 1132, 1139-40 (ND Ill 2004).

${ }^{104}$ See, e.g., Hunsinger $v$ State Pers. Bd., No C040744, 2003 WL 21268041 (Cal Ct App, June 3, 2003). In Connick v Myers, 461 US 138, 146 (1983), the Court set out the general rule that " $[w]$ hen employee expression cannot be fairly considered as relating to any matter of political, social, or other concern to the community, government officials should enjoy wide latitude in managing their offices, without intrusive oversight by the judiciary in the name of the First Amendment." Even Justice Brennan, dissenting in Connick, stated his view that "[p]erhaps the simplest example of a statement by a public employee that would not be protected by the First Amendment would be answering 'No' to a request that the employee perform a lawful task within the scope of his duties." Id at 164 n 3 (Brennan, $\mathrm{J}$, dissenting).
} 
countants. ${ }^{105}$ On pain of failure we require students in public schools to offer the right answers to questions, even if any particular student privately believes that these answers are false. ${ }^{106}$ On pain of punishment we require soldiers in the army to salute and exclaim "Yes, Sir" when they converse with an officer, even if any particular soldier personally believes that his officer does not merit these expressions of respect. ${ }^{107}$ On pain of tort liability we require doctors to communicate sufficient information to their patients to provide for informed consent, even if particular doctors privately believe that this information is misleading and harmful to their patients. ${ }^{108}$ These forms of compelled speech proceed without First Amendment scrutiny. If speech of this kind can be compelled, a fortiori the subsidization of this speech can also be compelled. If the former does not raise First Amendment questions, neither does the latter.

These examples suggest that compelling persons to subsidize speech with which they disagree does not automatically arouse First Amendment concerns. No doubt constitutional scrutiny can be triggered, and easily triggered, depending upon a variety of factors, including the nature of the speech, the context of the regulation, and so forth. But the mere fact that individuals have been compelled to subsidize speech with which they disagree is not sufficient to justify constitutional scrutiny. Constitutional review is not forthcoming unless it is also demonstrated that the required subsidization of speech compromises specifically First Amendment values. As I have already noted, and as the examples we have just considered attest, these values paradigmatically involve democratic self-governance and participation in the formation of public opinion. ${ }^{109}$

\footnotetext{
${ }^{105}$ See note 86 above.

${ }^{106}$ There are numerous cases filed by students asserting that they had supplied the correct answer on an examination and were graded incorrectly. In Susan M. v New York Law School, 76 NY2d 241 (1990), for example, a law student objected to losing credit because she answered based on New York law a question that was intended to test her knowledge of Delaware law. Affirming the right of educators to set their own standards for what constitutes a correct examination answer, the Court stated that "the pedagogical evaluation of her test grades [is] a determination best left to educators rather than the courts . . . ." Id at 243. See also Thomas A. Schweitzer, "Academic Challenge" Cases: Should Fudicial Review Extend to Academic Evaluation of Students? 41 Am U L Rev 267, 367 (1992) (surveying cases, and chronicling "the longstanding tradition of deference to academic evaluations [that] seems likely to remain strong for some time to come").

${ }^{107}$ McCord v Page, 124 F2d 68, 70 (5th Cir 1941) ("Military regulations requiring a soldier to salute his superior officers and ... the enforcement of the regulations by a proper military tribunal does not violate the Constitution of the United States.").

${ }^{108}$ Barcai v Betwee, 50 P3d 946 (Haw 2002); Brown v Dibbell, 595 NW2d 358 (Wis 1999).

${ }^{109}$ See note 89 above.
} 
Although there can be no comprehensive theoretical account of when state regulations implicate First Amendment values, we generally have well-developed constitutional intuitions about when restrictions on speech threaten to compromise First Amendment values. The problem is that these intuitions are clouded in the context of CSSD, because the very idea of compulsion seems constitutionally suspicious ${ }^{110}$ and because laws that coerce persons to pay for the speech of others are strange and unfamiliar. The resulting confusion is plainly evident in the painful uncertainty evinced by the Court in its Glickman-United Foods-Fobanns trilogy.

In the remainder of this essay, therefore, I shall postulate two simple heuristic principles that may prove helpful in educating our instincts in the context of CSSD. The principles function to connect the opaque and exotic circumstances of CSSD to the more familiar issues posed by cases involving compelled speech and restrictions on the subsidization of speech. I call these two principles the NonEndorsement Principle and the Symmetry Principle.

The Non-Endorsement Principle is activated whenever subsidizing objectionable speech puts an individual in the position of appearing to endorse that speech. If the Non-Endorsement Principle applies, claims of compelled subsidization of speech merge into claims of compelled speech. Whenever the Non-Endorsement Principle applies, therefore, claims of compelled subsidization of speech will trigger constitutional review if claims of compelled speech would trigger constitutional review.

Wooley is best understood as a case involving the Non-Endorsement Principle. Although it is implausible to imagine that George Maynard was compelled actually to speak, it is clear that he was compelled to subsidize state speech by displaying the New Hampshire motto on the license plate of his car. The Court's reference to a "mobile billboard" suggests that it interpreted existing social conventions as supporting the conclusion that those who display slogans on their automobiles endorse those slogans. The particular way in which New Hampshire forced Maynard to subsidize its motto, therefore, implicated the Non-Endorsement Principle, which converted Maynard's claim of compelled subsidization of speech into a claim of compelled speech.

Because strict constitutional scrutiny would have been triggered

${ }^{110}$ See United Foods, 533 US at $418 \mathrm{n}$ * (Stevens, J, concurring). 
if New Hampshire had compelled Maynard to affirm its motto, so strict constitutional scrutiny was triggered when New Hampshire instead forced Maynard to subsidize the display of its motto in a manner that could be understood as constituting endorsement. By contrast, if New Hampshire had merely required Maynard to display a license plate with numbers, it is very doubtful that First Amendment concerns would arise, because in such circumstances a claim of compelled speech would not trigger constitutional scrutiny. From a constitutional point of view, it would be no different than the state requiring Maynard to retain and display a social security card or a draft card. The application of the Non-Endorsement Principle thus does not trigger strict constitutional scrutiny unless, in the relevant context, a claim of compelled speech would trigger such scrutiny.

Not every subsidization of objectionable speech implicates the Non-Endorsement Principle. In PruneYard Shopping Center v Robins, ${ }^{11}$ for example, the Court held that state constitutional provisions authorizing "individuals to exercise free speech and petition rights on the property of a privately owned shopping center to which the public is invited"112 did not raise First Amendment concerns, even though these provisions required owners of shopping centers to make their property available for the speech of others with whom they could be in deep disagreement. ${ }^{13}$ The Court distinguished Wooley on the ground that the state constitutional provisions failed to implicate the Non-Endorsement Principle, because the views of persons "passing out pamphlets or seeking signatures for a petition . . . will not likely be identified with those of the owner."14

\footnotetext{
${ }^{111} 447$ US 74 (1980).

112 Id at 76.
}

${ }^{113}$ Recently, in Rumsfeld $v$ Form for Academic and Institutional Rights, 2006 WL 521237 (US March 6, 2006), the Court emphasized this distinction between the compelled subsidization of speech and the compelled endorsement of speech. Speaking in the context of a statute known as the Solomon Amendment that in effect required law shcools to subsidize the speech of military recruiters, the Court invoked Pruneyard and concluded that "[n]othing about recruiting suggests that law schools agree with any speech by recruiters, . . . We have held that high school students can appreciate the difference between speech a school sponsors and speech the school permits because legally required to do so, pursuant to an equal access policy."

${ }^{114}$ Id at 87 . The Court also noted two additional factors:

[N]o specific message is dictated by the State to be displayed on appellants' property. There consequently is no danger of governmental discrimination for or against a particular message. Finally, as far as appears here appellants can expressly disavow any connection with the message by simply posting signs in 
The distinction between compelled subsidizations of speech that implicate the Non-Endorsement Principle and those that do not is neatly captured in Fohanns' ruling that the case should be remanded to determine if plaintiffs can establish that the advertisements of the Beef Board and its Operating Committee were actually attributable to them individually. If the advertisements are not so attributable, plaintiffs' allegations would not implicate the Non-Endorsement Principle and accordingly their claim of compelled subsidization of speech would not merge with a claim of compelled speech.

The Symmetry Principle has two prongs. The first holds that if state restrictions on the ability of persons to pay for the speech of another do not raise First Amendment questions, so also state compulsions to pay for the speech of another will not, in the absence of special circumstances like a violation of the Non-Endorsement Principle, raise First Amendment questions. Although there are of course important differences between prohibitions of action and affirmative duties to act, these differences do not typically include First Amendment interests. If restrictions on the subsidization of speech do not raise First Amendment concerns, these concerns are unlikely to be created by the mere fact of legal compulsion, which does not independently infuse First Amendment values into transactions where these values are not otherwise present.

The point is well illustrated by regulations limiting the price of professional services. We pay high fees to lawyers or doctors in order to receive the benefit of their wisdom, but no First Amendment review would be required if the government were to limit professional fees. ${ }^{115}$ This is because we do not ordinarily regard the

the area where the speakers or handbillers stand.

Id.

${ }^{115}$ In recent years, an increasing number of legislatures and courts have placed hard limits on the amount a lawyer can receive in a contingency fee arrangement. See generally Richard M. Birnholz, Comment, The Validity and Propriety of Contingent Fee Controls, 37 UCLA L Rev 949, 951 n 9 (1990) ("Five states already impose a fixed or sliding scale maximum for all or most tort suits. Two states accomplish this by statute and three by court rule."). Such limits have been upheld by courts on several occasions. See, e.g., $A m$. Trial Lawyers Ass'n v N.7. Sup. Ct., 330 A2d 350 (NJ 1974); Gair v Peck, 160 NE2d 43 (NY 1959). Rather that raising First Amendment issues, these laws have been subject only to the general restriction that "[p]rice control, like any other form of regulation, is unconstitutional only if arbitrary, discriminatory, or demonstrably irrelevant to the policy the legislature is free to adopt, and hence an unnecessary and unwarranted interference with individual liberty." Nebbia v New York, 291 US 502, 539 (1934). No one considered the First Amendment to be implicated by the Economic Stabilization Act of 1970 (ESA), which authorized the Nixon Administration to impose price controls on goods and services. 
payment of fees for professional advice as transactions that are infused with First Amendment value. The Symmetry Principle would thus suggest that in the absence of special considerations First Amendment concerns would also not be raised by laws requiring the payment of professional fees. The fact of compulsion may arouse libertarian apprehensions, but it does not independently endow these transactions with specifically First Amendment values. That is why Newdow was correct to conclude that statutes providing for attorneys' fees ought not as a general matter to trigger First Amendment scrutiny. ${ }^{116}$ Certainly no one would claim that the order requiring Newdow to pay the fees of his wife's attorney implicates the Non-Endorsement Principle.

The second prong of the Symmetry Principle holds that if state restrictions on the ability of persons to pay for the speech of another do raise First Amendment questions, state requirements that persons affirmatively provide such support will likely trigger First Amendment review. I say "likely" because sometimes First Amendment interests are understood to inhere in the right of an audience to hear, rather than in the right of a speaker to communicate, ${ }^{117}$ and in such cases First Amendment scrutiny would be appropriate to review government efforts to restrict communication but not necessarily government efforts to compel communication. ${ }^{118}$ In the

The ESA was challenged (unsuccessfully) on grounds that it constituted an unconstitutional delegation of legislative power to the president. See Amalgamated Meat Cutters \& Butcher Workmen v Connally, 337 F Supp 737 (DDC 1971).

${ }^{116}$ The Symmetry Principle does suggest, however, that if restricting legal fees for public interest litigation would raise First Amendment questions, so also would the compulsory awarding of such fees. Compare Obralik v Obio State Bar Ass'n, 436 US 447 (1978), with In re Primus, 436 US 412 (1978). It would not follow that compulsory attorneys' fees would be unconstitutional in such circumstances, only that such fees would have to survive First Amendment review. On the distinction between First Amendment coverage and First Amendment protection, see note 82 above.

${ }^{117}$ From the Meiklejohnian perspective, for example, "the point of ultimate interest is not the words of the speakers, but the minds of the hearers." Alexander Meiklejohn, Political Freedom: The Constitutional Powers of the People 26 (1965). Meiklejohn famously remarked that "[w]hat is essential is not that everyone shall speak, but that everything worth saying shall be said." Id.

${ }^{118}$ This is because compelled expression would presumably increase the communication reaching an audience and so serve the underlying constitutional interest in providing an audience with information or opinion. This was the theoretical logic of Zauderer $v$ Office of Disciplinary Counsel, 471 US 626 (1985), in which the Court held that compelled disclosures in the context of commercial speech would raise only de minimis First Amendment concerns. Normally commercial speech, of the kind produced by the Beef Board and its Operating Committee, is constitutionally valued because of its "informational function," Cent. Hudson Gas \& Elec. Corp. v Pub. Servs. Comm'n, 447 US 557, 563 (1980), rather than because of a speaker's interests in disseminating it. See Post, Commercial Speecb at 14-15 
ordinary case, however, in which First Amendment rights attach to a speaker's decision to communicate or not to communicate, the Symmetry Principle holds that if a state restriction on the ability of a person to pay for speech triggers First Amendment review, so also will a state requirement that a person pay for speech, even if the Non-Endorsement Principle is not violated.

In Buckley $v$ Valeo, ${ }^{19}$ for example, the Court famously held that campaign "contribution and expenditure limitations" triggered First Amendment review because such requirements were constitutionally equivalent to direct "restrictions on political communication and association by persons, groups, candidates, and political parties." 20 The Symmetry Principle would suggest that Buckley gives us good ground to believe that compelling persons to contribute to specific political candidates would also raise First Amendment questions. $^{121}$

The Court in fact drew this implication in Abood $v$ Detroit Board of Education, ${ }^{122}$ which held that serious First Amendment questions were raised by a state law creating an agency shop in which all employees were required to pay to the union that was their collective bargaining agent a fee that was equal in amount to union dues. Abood invoked Buckley to justify the conclusion that " $[\mathrm{t}] \mathrm{o}$ compel employees financially to support their collective-bargaining rep-

(cited in note 89). Zauderer noticed that the "informational function" of commercial speech is not compromised when commercial speech is compelled, as distinct from restricted, because the compulsion increases the flow of information to an audience, and hence better serves the constitutional values at stake in commercial speech. But in United Foods the Court appears to have held that the First Amendment protects the rights of commercial speech speakers, rather than the rights of an audience wishing to receive the information conveyed by commercial speech. fobanns builds on this holding. If the Court is serious about this theoretical shift in the constitutional status of commercial speech, it will have to alter many fundamental aspects of commercial speech jurisprudence, including the application of overbreadth doctrine, the permissibility of prior restraints, the constitutionality of required disclosures of the kind approved by Zauderer, and so on. This is a complicated question that I discuss in Robert Post, Compelled Commercial Speech and Coerced Commercial Association: United Foods, Zauderer, and Abood, 40 Valparaiso U L Rev 1 (2006).

119424 US 1 (1976).

${ }^{120} \mathrm{Id}$ at 19. "A restriction on the amount of money a person or group can spend on political communication during a campaign necessarily reduces the quantity of expression by restricting the number of issues discussed, the depth of their exploration, and the size of the audience reached. This is because virtually every means of communicating ideas in today's mass society requires the expenditure of money." Id at 19. See also Simon $\dot{\sigma}$ Scbuster, Inc. v Members of N.Y. State Crime Victims Bd., 502 US 105 (1991).

${ }^{121}$ This should be contrasted to the use of government tax dollars to subsidize elections in a viewpoint neutral manner. Buckley, 424 US at 86-93; May $v$ McNally, 55 P3d 768 (Ariz 2002).

122431 US 209 (1977). 
resentative has an impact upon their First Amendment interests. An employee may very well have ideological objections to a wide variety of activities undertaken by the union in its role as exclusive representative." 123

One of the principles underlying the Court's decision in Buckley $v$ Valeo was that contributing to an organization for the purpose of spreading a political message is protected by the First Amendment. Because "(m)aking a contribution . . . enables like-minded persons to pool their resources in furtherance of common political goals," the Court reasoned that limitations upon the freedom to contribute "implicate fundamental First Amendment interests."

The fact that the appellants are compelled to make, rather than prohibited from making, contributions for political purposes works no less an infringement of their constitutional rights. For at the heart of the First Amendment is the notion that an individual should be free to believe as he will, and that in a free society one's beliefs should be shaped by his mind and his conscience rather than coerced by the State. . . .

These principles prohibit a State from compelling any individual to affirm his belief in God, or to associate with a political party, as a condition of retaining public employment. They are no less applicable to the case at bar, and they thus prohibit the appellees from requiring any of the appellants to contribute to the support of an ideological cause he may oppose as a condition of holding a job as a public school teacher. ${ }^{124}$

Because Buckley had held that government restrictions of "support of an ideological cause" raised First Amendment issues, so Abood held that governmentally compelled support for such causes would raise analogous First Amendment issues, even if the speech sustained by this support could not be attributed to the contributor. The Court affirmed a symmetry between restrictions and compulsions, a symmetry that expressed the view that the same First Amendment values were implicated in each. The Court subsequently reaffirmed this symmetry in Keller $v$ State Bar of California, ${ }^{125}$ which read Abood to hold "that just as prohibitions on making contributions to organizations for political purposes implicate fundamental First Amendment concerns, see Buckley $v$ Valeo, 'compelled . . . contri-

\footnotetext{
${ }^{123} \mathrm{Id}$ at 222.

${ }^{124}$ Id at 234-35 (citations omitted).

125496 US 1 (1990).
} 
butions for political purposes work no less an infringement of . . . constitutional rights."'126

United Foods cites Abood and Keller for the broad-ranging proposition that "mandated support is contrary to . . . First Amendment principles . . .."127 This proposition now forms the basic premise of CSSD. In his fobanns dissent, Souter explicitly affirms this premise and attributes it to Abood and Keller. ${ }^{128}$ Nothing that Scalia says in his majority opinion in Jobanns in any way limits or disavows this premise, which therefore remains the law in CSSD cases that do not involve government speech. But this premise rests on a misreading of Abood and Keller. These decisions do not hold that the compelled subsidization of speech always raises First Amendment concerns. They instead stand for the Symmetry Principle. They hold that if restrictions on subsidies for speech raise First Amendment concerns, so likely will mandated support for such speech.

The Symmetry Principle is helpful primarily because we have well-developed (if untheorized) intuitions about when restrictions on the funding of speech will trigger constitutional scrutiny. We can use these intuitions to guide us in the newer and far less familiar context of compelled subsidization of speech. Fohanns illustrates the utility of this approach. The Symmetry Principle suggests that if government limitations on direct contributions to the state would not raise First Amendment concerns, so also, in the absence of special considerations like a violation of the Non-Endorsement Principle, compelled contributions to the state would not trigger First Amendment scrutiny. Since I very much doubt that we would regard such limitations as triggering First Amendment scrutiny, ${ }^{129}$ the Symmetry Principle would predict that the use of compulsory taxes to support government speech ought not to trigger First Amendment review.

The heuristic value of the Symmetry Principle is that it can help us understand how the government speech exception can be inte-

\footnotetext{
${ }^{126}$ Id at 9-10 (quoting Abood, 431 US at 234).

${ }^{127}$ United States $v$ United Foods, Inc., 533 US 405, 413 (2001).

${ }^{128}$ Souter cites Abood and Keller as "authority for the . . . proposition that, absent substantial justification, government may not force targeted individuals to pay for others to speak." Johanns v Livestock Mtkg. Ass'n, 125 S Ct 2055, 2069-70 (Souter, J, dissenting).

${ }^{129}$ See, e.g., Tenn Code Ann $\$ 64-7-110$ (a)(16)(B) (2004) (prohibiting in certain circumstances private contributions to regional development authorities).
} 
grated into a coherent account of First Amendment jurisprudence, which neither Scalia nor Souter is able to do. The Symmetry Principle suggests that the explanation for the government speech exception lies in the question of why government can prohibit contributions to the state without raising First Amendment concerns. The rationale of Buckley points toward an answer. Government restrictions on the ability to pay others to speak for us in public debate compromise our ability to participate in public discourse in ways that seek to make the state democratically responsive to our own views. ${ }^{130}$ Such restrictions compromise First Amendment values connected to the project of democratic legitimation. These values are not at stake, however, when government restricts contributions to the state.

Because the state always speaks for the community as a whole, and never for the personal views of private citizens, the state can never become the personal spokesperson of a citizen, no matter how much money she donates to it. The state cannot properly become an instrument by which private persons attempt to make public opinion responsive to their own particular views. It follows that restrictions on donations to the state do not compromise the ability of persons to participate in public discourse. By calling our attention to this conclusion, the Symmetry Principle allows us to see that neither government restrictions on donations to the state, nor government requirements that persons contribute to the state, compromise First Amendment values connected to the project of democratic legitimation, although such restrictions or compulsions might well compromise these values in the context of contributions to a private person.

This suggests that the fundamental constitutional question posed by the government speech exception in fobanns is whether the Beef Board advertisements, generically considered, should be understood as "speaking for" the private and particular views of the beef industry, which represents the perspective of one group in the community, or instead as "speaking for" the official views of the state, which represents the outlook of the whole community. Cases like Glickman, United Foods, and fobanns are difficult because the industry programs created by Congress are ambiguous mixtures of public and private, so that it is hard to characterize the promotional ma-

${ }^{130}$ See Robert Post, Reconciling Theory and Doctrine in First Amendment furisprudence, 88 Cal L Rev 2355, 2366-68 (2000). 
terial that they produce. It is unclear whether to classify this material for constitutional purposes as expressing the private perspectives of the cattle industry or instead as expressing the public views of the state. The formalism of Scalia's opinion may be as satisfactory a way as any to resolve this question, because, as he notes, if "the government sets the overall message to be communicated and approves every word that is disseminated,"131 it is fair to conclude that the message speaks for the official views of the government, rather than for the particular views of private industry. ${ }^{132}$

Neither Scalia nor Souter can accept this explanation of the government speech exception, however, because each postulates that the fundamental First Amendment interest at issue in CSSD is autonomy, rather than participation in public debate. ${ }^{133}$ The difficulty with regarding autonomy as a fundamental First Amendment interest is that it is omnipresent; every restriction and compulsion will to some degree compromise autonomy. It is precisely for this reason that autonomy is not usefully regarded as a foundational First Amendment interest. ${ }^{134}$ Autonomy cannot explain why First

\footnotetext{
${ }^{131}$ Johanns, $125 \mathrm{~S} \mathrm{Ct}$ at 2063. See note 41 above.

${ }^{132}$ Some lower courts have instead focused on the question of whether the speech produced by these ambiguous organizations is in fact unduly influenced by private perspectives. See note 38 above. Although this question is theoretically justified, it is not clear that it is judicially administrable. It is certainly not unreasonable for the Court to hold that it is

${ }^{133}$ See notes 36, 40, and 54 above.

${ }^{134}$ There is a slight indication that Souter may have in mind the constitutional value of protecting conscience, rather than protecting autonomy. Souter begins his dissent by noting:
} not.

In 1779 Jefferson wrote that "to compel a man to furnish contributions of money for the propagation of opinions which he disbelieves, is sinful and tyrannical." 5 The Founders' Constitution, $\$ 37$, A Bill for Establishing Religious Freedom, p. 77 (1987), codified in 1786 at Va. Code Ann. $\$ 57-1$ (Lexis 2003). Although he was not thinking about compelled advertising of farm produce, we echoed Jefferson's view four years ago in United Foods, where we said that "First Amendment values are at serious risk if the government can compel a particular citizen, or a discrete group of citizens, to pay special subsidies for speech on the side that it favors...." 533 US at 411 .

fobanns, $125 \mathrm{~S} \mathrm{Ct}$ at 2069 (Souter, J, dissenting). Jefferson's observation, which is frequently cited in the context of compelled speech cases, concerned the issue of the use of government tax revenue to support an established church. R.7. Reynolds Tobacco Co. $v$ Sbewry, 384 F3d $1126,1140-41$ (9th Cir 2004). There is a tradition in our law and our history that such taxation would compromise conscience. See Flast $v$ Coben, 392 US 83 (1968); Noah Feldman, The Intellectual Origins of the Establishment Clause, 77 NYU L Rev 346, 404 (2002). Souter may have meant, therefore, that compelled subsidization of government speech potentially violates the conscience of taxpayers, in the same way that the use of taxes to support an established church is understood to violate the conscience of taxpayers. There 
Amendment interests are sometimes triggered and sometimes not. ${ }^{135}$

To understand the actual shape of First Amendment jurisprudence, we must postulate a constitutional interest that is implicated in some circumstances, but not in all circumstances. If the circumstances in which an interest is involved happen to correspond to the actual pattern of First Amendment cases, we have a good candidate for the First Amendment interest that is in fact driving judicial decision making. The interest of autonomy, which would be compromised by compulsory taxation as well as by the compelled payment of attorneys' fees at issue in Newdow, does not well explain the configuration of existing or desirable First Amendment jurisprudence. The interest of participation in public debate, by contrast, which is involved neither in compelled contributions to the state nor in compelled contributions to a private lawyer in a private case, ${ }^{136}$ does have considerable explanatory power in explaining the government speech exception, as well as the contours of CSSD generally.

\section{Conclusion}

Johanns is a welcome development, but it leaves in place the central premise of CSSD, which is that every compelled subsidization of objectionable speech requires First Amendment review. This premise derives from a misreading of Abood and Keller, and it gives clear doctrinal expression to the idea, advanced by both Scalia and Souter, that autonomy is a fundamental First Amendment interest which is always at stake whenever the state forces persons to pay for the speech of others. This idea is demonstrably false unless the Court plans to constitutionalize many common legal requirements that no one presently regards as raising First Amendment issues. ${ }^{137}$

are many difficulties with this line of thought, however. It is odd to speak of violations of conscience in the context of nonideological speech like beef advertisements. And whereas the connection between conscience and religion is well explored, the relationship between conscience and speech is not. Most fundamentally, conscience, like autonomy, would seem to prove too much, because it is potentially indiscriminate. Newdow would seem to have a claim of conscience that is at least equal in force to those of the beef producers in Jobanns.

${ }^{135}$ See Post, 88 Cal L Rev at 2372 (cited in note 129).

${ }^{136}$ See note 115 above.

${ }^{137}$ See text at notes $78-107$. 
So long as the central premise of CSSD remains unrevised, however, the holding of fohanns can serve as nothing more than a kind of force majeur necessary to foreclose potentially embarrassing applications of the compelled subsidization of speech doctrine. The lesson of Newdow is that in the future the Court will be required to announce other equally ad hoc decisions. The only hope of avoiding a string of precedents as self-evidently ragged as the Glickman-United Foods-fobanns trilogy is to repudiate the premise of CSSD and to rethink the fundamental question of when the compelled subsidization of speech does and does not raise First Amendment issues. This may in turn require reconceptualizing the nature of the fundamental interests which the First Amendment should be interpreted to protect in the context of compulsions to speak. This essay is meant to be a first small step in that direction. 